\title{
Do Patient Characteristics And Duration of Re- sponse to Hormonal Therapy Predict Outcomes of Post-Docetaxel Abirateron Acetate Treatment in Prostate Cancer?
}

\author{
Goksen INANC IMAMOGLU ${ }^{1}$, Tulay EREN ${ }^{1}$, Nuriye YILDIRIM OZDEMIR ${ }^{2}$, \\ Cengiz KARACIN ${ }^{1}$, Sertac CIMEN ${ }^{3}$, Ebru CILBIR ${ }^{1}$, Dogan YAZILITAS ${ }^{1}$ \\ ${ }^{1}$ University of Health Sciences, Diskapi Yildirim Beyazit Research and Training Hospital, Department of Medical Oncology \\ ${ }^{2}$ Yildirim Beyazit University, Numune Research and Training Hospital, Department of Medical Oncology \\ ${ }^{3}$ University of Health Sciences, Diskapi Yildirim Beyazit Research and Training Hospital, \\ Department of Urology, Ankara, TURKEY
}

\begin{abstract}
A portion of castration-resistant prostate cancer patients are given abiraterone acetate treatment after docetaxel chemotherapy. In this study, we analyzed the association of patient characteristics and time to castration-resistant prostate cancer (TTCRPC) with secondary hormonal treatment-related progression-free survival. Data of patients whom were treated with Abiraterone Acetate (AA) for metastatic castration-resistant prostate cancer (mCRPC) in two different oncology centers between 2010 and 2018 were analyzed retrospectively. The entire patient group consisted of 76 patients however 13 of them were excluded due to incomplete data. Comparative results were obtained in 63 patients. Mean duration of primary hormonal therapy was 20 months. Docetaxel chemotherapy was administered as 7 cycles and mean duration of remission was 9 months. Mean progression-free survival post-AA treatment was calculated as 27 months. In univariate analysis, prostate specific antigen (PSA) level lower than median PSA at the time of initial diagnosis and a total Gleason score of below 8 was significantly consistent with prolonged progression-free survival (PFS). In multivariete analysis, it was observed that only PSA level at the time of initial diagnosis affected the PFS. Progression-free survival after Abiraterone Acetate treatment in patients with previous hormonal therapy duration longer than 18 months was better than the survival in the patient group who had a shorter hormonal therapy duration. The former group experienced a 39\% risk reduction. In the light of these findings, we may recommend the administration of the Androgen Receptor (AR)-targeted treatment option in patients with low PSA levels at the time of diagnosis and patients with long castration duration after chemotherapy.
\end{abstract}

Keywords: Hormonal treatment, Abiraterone acetate, Time to castration resistant prostate cancer, Prostate cancer

ÖZET

Prostat Kanserinde Hasta Özellikleri Ve Hormonal Tedaviye Yanıtın Süresi, Docetaksel Sonrası Abirateron Tedavisinin Sonuçlarını Öngörüyor mu?

Kastrasyona dirençli prostat kanseri tedavisinde dosetaxel sonrası abirateron asetat uygulanan hastalarda hasta karakteristikleri ve kastrasyon direnci zamanı (time to castration resistan prostate cancer-TTCRPC) ile ikincil hormonal tedaviye bağlı progresyonsuz sağkalım arasındaki ilişkiyi belirlemek için bu çalışma planlandı. 2010 ve 2018 yılları arasında Ankara'da iki Onkoloji merkezinde metastatik kastrasyon rezistan prostat kanseri (mCRPC) tedavisi sonrası Abirateron Asetat (AA) ile tedavi edilen hastaların verileri retrospektif olarak analiz edildi. Sonuçları değerlendirilen 76 hastaya hastane etik kurul onayı alındı. Hastaların 63'ünde karşılaştırmalı sonuçlar elde edildi. Ortalama Androjen Deprivasyon Süresi (ADT) 20 aydı. Dosetaksel kemoterapisi ortalama 7 kür uygulandı ve 9 aylık ortalama remisyon süresi görüldü. Abirateron Asetat sonrası ortalama progresyonsuz sağkalım 27 ay olarak hesaplandı.

ORCIDS: Tulay Eren: $\quad 0000-0002-0088-1149$ Sertac Cimen: 000-0002-0252-8840
Nuriye Yildirim Ozdemir: 0000-0002-9235-9592 Ebru Cilbir:

0000-0001-8967-2505
Cengiz Karacin: 0000-0002-7310-9328 Dogan Yazilitas: 0000-0003-3850-7870 
Tek değişkenli analizde, hastanın tanı anındaki PSA değerinin ortalama değerden düşük olması ve 8'in altındaki Gleason skoru uzamış progresyonsuz sağkalım ile anlamlı olarak uyumlu olarak bulundu. Çok değişkenli analizde ise, yalnızca PSA'nın tanı anındaki değerinin progresyonsuz sağkalımı etkilediği gözlendi. Önceki hormon tedavisi 18 aydan uzun olan hastalardaki AA sonrası progresyonsuz sağkalım süresi belirgin olarak iyi gözlendi ve \%39 oranında risk azalması saptandı. Bu bulgular ışı̆ıında, tanı anında PSA değeri düşük olan ve uzun kastrasyon direnci zamanı olan hastalara kemoterapiden sonra progresyon olduğunda, Androjen Reseptörü (AR) ekseni hedefli tedavi seçeneğinin uygulanmasını önerebiliriz.

Anahtar Kelimeler: Hormonal tedavi, Abirateron asetat, Kastrasyon direnci zamanı, Prostat kanseri

\section{INTRODUCTION}

Prostate cancer constitutes approximately 15\% of all cancer cases in males with the highest prevalance and the second highest incidence. ${ }^{1}$ However, the incidence of prostate cancer differs in various geographical areas of the world. While it is much more common in North America, Western and Northern Europe (85/100000), it is lessfrequently diagnosed in Eastern and Southern Asia (4.5/100000). On the other hand, despite these differences in its incidence, the mortality rates do not differ significantly; mortality rates in the same regions are 24/100000 and 2.9/10000 respectively. ${ }^{1,2}$

It is known that the growth and persistance of prostate cancer cells depend on the induction of androgen receptors (AR) by testosterone and dihydrotestosterone. ${ }^{3}$ Recognition of this mechanism led to consideration of androgen deprivation treatment as the main treatment option in metastatic prostate cancer. Nevertheless, most of these patients progress to castration-resistant prostate cancer (CRPC).

It was shown that AR signals take role in the pathogenesis of CRPC. In line with this, it was reported that agents such as Abiraterone Acetate (AA) and Enzalutamide which target ARs can be used before or after docetaxel -which is the standard treatment in CRPC- in order to prolong PFS and total survival. ${ }^{4-7}$ However, in our country, an official permission from the Ministry of Health is required in order to give these medications prior to docetaxel chemotherapy (CT).

Despite the fact that docetaxel chemotherapy is standard of care, currently there are no standards regarding secondary hormonal manipulations. In this study, we aimed to analyze the predictive factors for the success of AA treatment when given as a secondary hormonal treatment in the setting of CRPC.

\section{PATIENTS AND METHODS}

\section{Patient Selection}

Patients who were diagnosed with metastatic castration resistant prostate cancer (mCRPC) and treated with AA in two oncology centers in Ankara between 2010 and 2018 were included in this study. Patients with incomplete data were excluded. All patients underwent androgen deprivation therapy (ADT) for mCRPC by surgical or medical castration with luteinizing hormone releasing hormone (LHRH) analogues or maximum androgen blockage. Metastases were confirmed by bone scintigraphy, computerized tomography and magnetic resonance imaging.

\section{Evaluation Criteria}

Data including age at the time of diagnosis, serum PSA level, Gleason score, metastasis status (site and number), Eastern Cooperative Oncology Group (ECOG) performance and pain scores were all retrieved from the patient databases. Type and duration of androgen deprivation therapy were also recorded. Biochemical and/or radiological proof of disease progression while the patient was under ADT with a serum testosterone of below $50 \mathrm{ng} /$ $\mathrm{dL}$ was defined as CRPC. Biochemical progression was diagnosed as per Prostate Cancer Working Group 2 (PCWG2) criteria, while radiological progression was defined as per RECIST (Response Evaluation Criteria in Solid Tumors) 1.1 criteria. ${ }^{8,9}$ Duration between androgen deprivation therapy initiation time and CRPC diagnosis time was defined as time to castration resistant prostate cancer 


\begin{tabular}{|ll|}
\hline Table 1. Demographic data \\
\hline \\
Age, median (min-maks) & n: 63 \\
Gleason Score, (IQR) & $65(55-80)$ \\
PSA, ng/mL, (IQR) & $8(2)$ \\
More than 5 bone metastases, No. (\%) & $75(124)$ \\
LHRH, No. (\%) & $46(74)$ \\
Orchiectomy & $51(80.9)$ \\
Bicalutamide, No, (\%) & $11(17.5)$ \\
PS, No. (\%) & $52(82.5)$ \\
$\quad$ 0-1 & $36(57.1)$ \\
2 & $27(42.8)$ \\
Duration of HT, month. (IQR) & $20(21)$ \\
Duration of CT, month. (IQR) & $9(7)$ \\
\hline $\begin{array}{l}\text { PSA: Prostate Specific Antigen, LHRH: Luteinizing Hormone-Releas- } \\
\text { ing Hormone, PS: Performance Status, HT: Hormonotherapy, CT: } \\
\text { Chemotherapy }\end{array}$ \\
\hline
\end{tabular}

(TTCRPC). Docetaxel chemotherapy was given to patients diagnosed with CRPC. Duration of chemotherapy and total number of chemotherapy cycles were also recorded. Chemotherapy duration was defined as the time period between the initiation of chemotherapy and commencement of the secondary hormonal therapy (HT).

As per our protocol, 6 cycles (each cycle with 3-week duration) docetaxel chemotherapy was planned for all CRPC patients. The total chemotherapy cycle number was increased in the case that there is significant response to CT. Progression in disease symptoms and/or serum PSA level increase were considered as failure of CT. Bone scintigraphy and other imaging studies were performed as needed.

Patients who had disesase progression despite chemotherapy were given AA treatment. These patients received either 5 or $10 \mathrm{mg}$ oral prednisone in addition to $1000 \mathrm{mg}$ AA per day. These patients who consisted the study group were evaluated periodically at the outpatient clinics for symptom assessments, pain scoring and serum PSA level measurements. Patients with high pain scores were either prescribed opioids or referred to Radiation Oncology department for palliative radiotherapy. Adverse effects due to medications were also as-

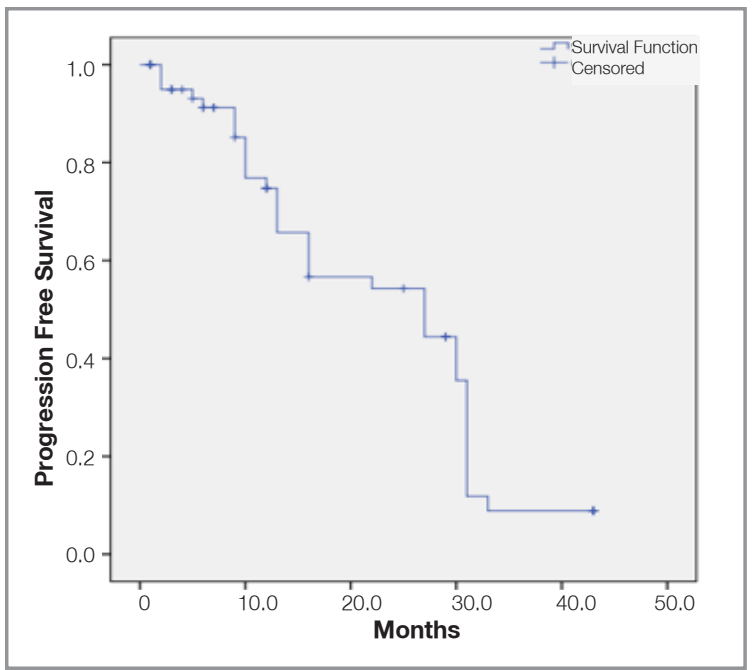

Figure 1. Progression-free survival

sessed and recorded during these encounters. Progression-free survival (PFS) of the patients post-AA therapy were recorded. Post-AA PFS was defined as the time period between the commencement of AA therapy and diagnosis of disease progression or patient death.

\section{Statistical Analysis}

Statistical analysis were performed by SPSS (Statistical Package for Social Sciences) 20.0 software. Distribution of data were assessed by Kolmogorov Smirnov test. Median values were calculated for non-parametric quantitative data while case numbers (n) and percentages (\%) were used for qualitative data analysis. Mann-Whitney U test was used for comparison between groups for non-parametric data analysis. Kaplan-Meier method and univariate cox regression model were used for calculation of PFS and hazard ratios.

\section{RESULTS}

The entire patient group consisted of 76 patients however 13 of these patients who had incomplete data were excluded. Characteristics of the remaining 63 patients are displayed in Table 1. 
International Journal of Hematology and Oncology

\begin{tabular}{|lll|}
\hline \multicolumn{2}{|l|}{ Table 2. Univariete analyses } \\
\hline & HR (95\% Cl) & p \\
\hline Age & $1.04(0.56-1.92)$ & 0.873 \\
Gleason score & $2.47(1.21-5.03)$ & 0.012 \\
PSA & $2.61(1.28-5.30)$ & 0.008 \\
Bone metastases & $1.35(0.71-2.57)$ & 0.504 \\
Performance score & $0.66(0.35-1.22)$ & 0.186 \\
HT 12 months & $1.43(0.72-2.85)$ & 0.272 \\
HT 18 months & $0.61(0.34-1.13)$ & 0.267 \\
HT 24 months & $1.34(0.73-2.46)$ & 0.254 \\
CT 8 months & $0.81(0.45-1.48)$ & 0.883 \\
\hline
\end{tabular}

\begin{tabular}{|c|c|c|}
\hline & HR (95\% Cl) & $\mathbf{p}$ \\
\hline Gleason score & $1.32(0,33-5.24)$ & 0.694 \\
\hline PSA & $2.41(1.18-5.10)$ & 0.008 \\
\hline
\end{tabular}

Mean androgen deprivation therapy duration was 20 months. Standard docetaxel chemotherapy was given as 7 cycles and mean duration of postchemotherapy remission was 9 months. Mean post-chemotherapy progression-free survival was calculated as 27 months (Figure 1).

\begin{tabular}{|c|c|c|c|}
\hline & Median PFS & 95\% Confidence Interval & $\mathbf{p}$ \\
\hline \multicolumn{4}{|l|}{ Age } \\
\hline 65 and below & 27.00 & $(17.60-36.39)$ & 0.873 \\
\hline 65 over & 30.00 & (22.09-37.90) & \\
\hline \multicolumn{4}{|l|}{ Gleason } \\
\hline 8 below & 33.00 & (6.33-59.66) & 0.012 \\
\hline 8 and over & 27.00 & $(17.42-36.57)$ & \\
\hline \multicolumn{4}{|l|}{ PSA } \\
\hline 75 below & 33.00 & (6.33-59.66) & 0.008 \\
\hline 75 and over & 27.00 & $(17.52-36.47)$ & \\
\hline \multicolumn{4}{|l|}{ Bone metastases } \\
\hline 5 below & 27.00 & $(18.13-35.86)$ & 0.504 \\
\hline 5 and over & 22.00 & $(16.81-27.19)$ & \\
\hline \multicolumn{4}{|l|}{ Performance Score } \\
\hline 0 & 27.00 & (19.44-34.55) & 0.186 \\
\hline $1-2$ & 31.00 & $(27.12-34.87)$ & \\
\hline \multicolumn{4}{|l|}{ Duration } \\
\hline \multicolumn{4}{|l|}{ of Hormonotherapy } \\
\hline 12 months and below & 16.00 & (6.05-25.95) & 0.272 \\
\hline Longer than 12 months & 31.00 & (20.80-38.22) & \\
\hline 18 months and below & 16.00 & (6.64-25.35) & 0.267 \\
\hline Longer than 18 months & 30.00 & $(20.87-39.12)$ & \\
\hline 24 months and below & 27.00 & $(11.43-42.56)$ & 0.254 \\
\hline Longer than 24 months & 31.00 & $(25.58-36.41)$ & \\
\hline \multicolumn{4}{|l|}{ Duration of Chemotherapy } \\
\hline 8 months and below & 31.00 & $(10.09-41.35)$ & 0.883 \\
\hline Longer than 8 months & 27.00 & $(14.85-39.15)$ & \\
\hline
\end{tabular}




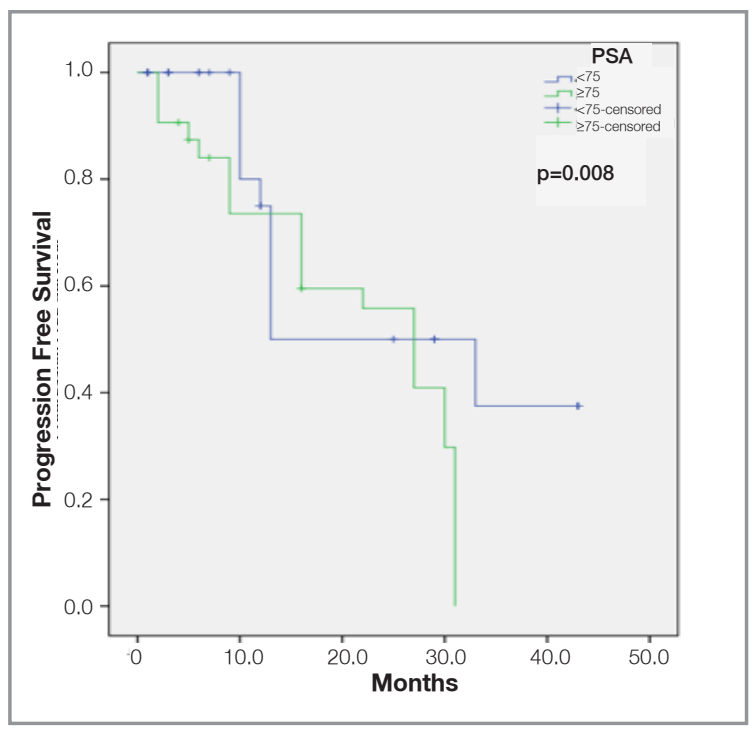

Figure 2. PSA related progression-free survival

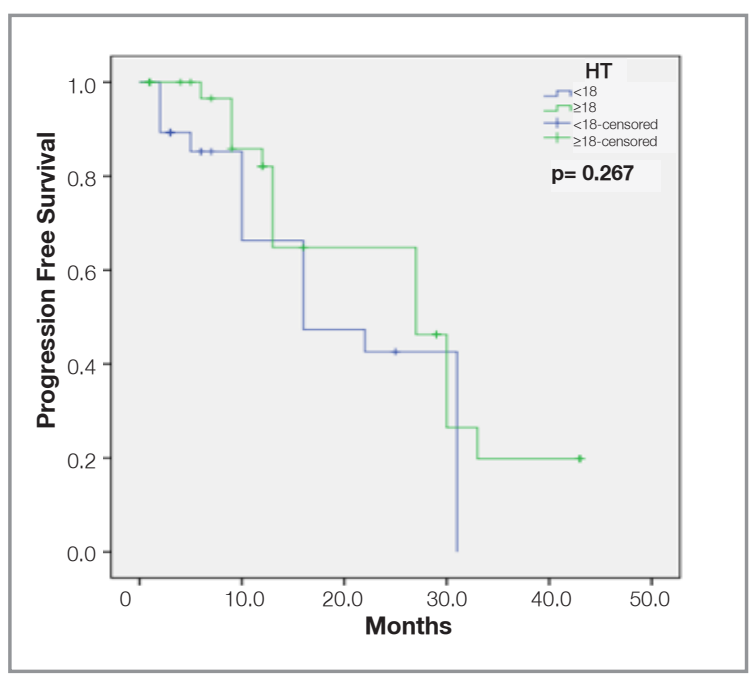

Figurel 4. HT related progression-free survival (cut-off 18 months)

Hazard ratios in univariete analysis are summarized in Table 2. Hazard ratios were calculated based on the comparative analysis performed according to patient age (i.e. below or above mean patient age), serum PSA level (below or above mean serum PSA level), Gleason score (below or above 8), metastatic site number (below or above 5) and ECOG performance score (below or above 2). Duration of hormonal treatment were compared according to 12 th, 18th and 24th months.

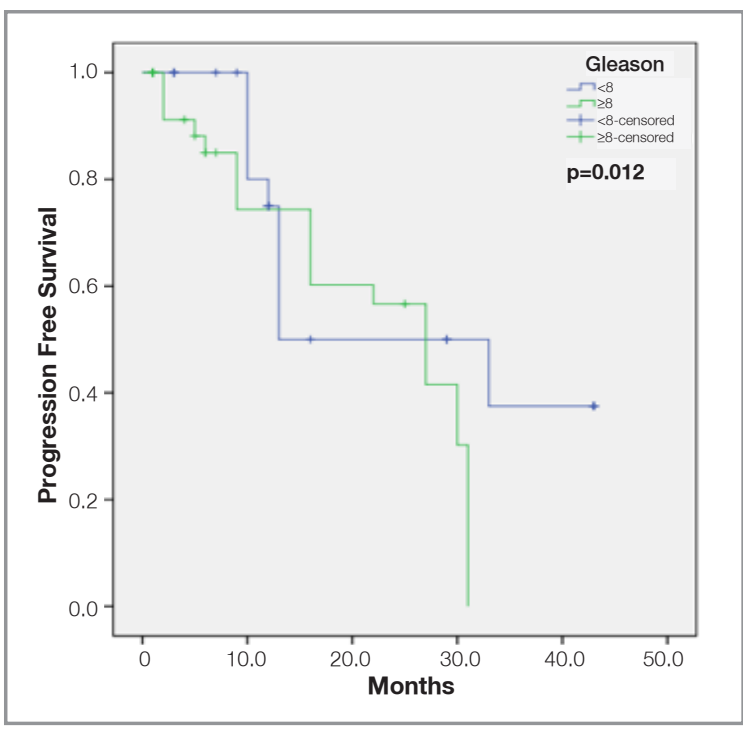

Figure 3. Gleason related progression-free survival

This analysis revealed that serum PSA below mean level and Gleason score of below 8 significantly correlated with low progression risk. In addition, patients with an ADT duration of longer than 18 months benefited from a $39 \%$ decrease in progression risk when compared with the patients who had an ADT duration of shorter than 18 months (HR:0.61). As such, a chemotherapy duration of longer than 8 months led to a $19 \%$ reduction in progression (HR: 0.81). The multivariate analysis of significant findings is presented in Table 3. Multivariete analysis revealed that serum PSA level below mean correlated with prolonged PFS.

Progression-free survival rates of patient subgroups are displayed in Table 4. Progression-free survival curves between patients with PSA values below $75 \mathrm{ng} / \mathrm{ml}$ and patients with Gleason scores below 8 and those with higher values are shown in Figures 2 and 3. The progression-free survival curve between patients with an ADT duration of more than 18 months and patients with progression in a shorter period is also shown in Figure 4. Patients who were given an ADT of longer than 18-month duration had longer PFS.

\section{DISCUSSION}

There are different androgen receptor-related treatment options, immunotherapy regimes and chemo- 
therapy protocols available for patients diagnosed with CRPC. However, the question "which therapy is ideal for which patient?" still needs to be answered. Today, most of the authors prefer androgen receptor-related therapies due to their encouraging safety profile and feasibility. Nevertheless, there are not any standardized parameters for predicting the success of these treatments. Some biomarkers have been tested previously in this regard. ${ }^{10}$

It has been proposed that androgen receptor splice variant 7 (ARV7) can be used for predicting the efficacy of secondary hormonal treatments such as AA and Enzalutamide. Detection of ARV7 in circulating tumor cells seemed to be related with a resistance to these treatments. ${ }^{10}$ However, this test is very expensive and inconvenient for clinical usage.

In a study about the efficacy of AA treatment which included 762 patients, serum lactate dehydrogenase level above normal range, an ECOG performance score of above 2, presence of liver metastasis, a serum albumin level of $\leq 4 \mathrm{~g} / \mathrm{dl}$ and a high serum alkaline phosphatase level were reported as unfovourable prognostic factors. ${ }^{11}$ In another study, the authors focused on the PSA response and concluded that a 50\% reduction in serum PSA level in a period of 15 days after initiation of AA treatment correlated with prolonged PFS and overall survival (OS). ${ }^{12}$ A retrospective report including 553 patients concluded that low biopsy Gleason scores, absence of metastasis and low serum PSA levels were associated with a higher ADT efficacy. ${ }^{13}$

Our study revealed that patient age did not have a significant impact on the outcomes of secondary hormonal therapy. In line with the previous reports, high Gleason scores and serum PSA levels were associated with an unfavourable prognosis in our study. Statistically, patients with lower PSA and Gleason score at the time of diagnosis had more significant PFS rates and responded better to Abiraterone Acetate treatment. In multivariate analysis, only low PSA value was found as a significant factor.

We did not include the patients with visceral metastasis in our study. In a report which analyzed the influence of visceral metastasis on disease progression, the authors concluded that it was associated with a poor survival rate. ${ }^{14}$ In another study, au- thors noted that CRPC patients with visceral metastasis were not good candidates for secondary hormonal treatments. ${ }^{15}$

It has been suggested that familial gene polymorphisms in androgen metabolic pathways are related with the disease progression after initiation of ADT. ${ }^{16,17}$ In a study including 173 patients who were given secondary hormonal treatment for metastatic CRPC, post-AA therapy median PFS was 3 months longer in the patient group who gave a good response to ADT (ADT > 12 months) when compared with the group with a worse response (5.8 vs 2.8 months, respectively). ${ }^{15}$ Another study which recruited 132 patients with mCRPC suggested that a TTCRPC of $<12$-month duration was related with an unfavourable prognosis and a weak response to secondary hormonal manipulations. ${ }^{18}$

Some studies reported that a TTCRPC shorter than 2-year was an independent predictor of post-CT OS and had a critical importance for increased PFS. ${ }^{19}$ An Italian study revealed that patients with a TTCRPC of longer than 28 months experienced a higher 5-year OS (74\% vs 50\%, p=0.14). ${ }^{20} \mathrm{In}$ another report, it was noted that patients who developed a quick hormonal therapy resistance had a lower PFS and OS with AA and Enzalutamide when compared with the patients who received ADT for a time period longer than 1-year. ${ }^{21}$ However, this study did not determine ADT duration as an independent predictor of future AR-targeted therapy success.

In our study, the resistance to castration, which was thought to be influential on mean PFS after AA, was compared with taking cut-offs at 12, 18 and 24 months. According to the results, it was observed that duration of progression-free survival was the best in patients with a maximum hormonal treatment duration of longer than 18 months, but there was no significant statistical value. The patient group with hormonal treatment duration longer than 18 months has a $39 \%$ decrease in risk compared to patients with short hormonal response. However, according to the results of our study, there is not enough data to indicate that duration of hormonal treatment is an independent predictor. Serum PSA level at the time of diagnosis, Gleason 
score, number of metastatic sites and performance scores should all be considered for prediction of these treatments' efficacy.

In this study, we did not find a relationship between CT duration and the duration of hormonal therapy. Patients whose CT duration was above the median (i.e. 8 months) experienced a $19 \%$ progression risk reduction however this difference was not statistically significant. This finding is in line with the results reported by Angelergues et al. ${ }^{18}$ These authors concluded that there was no relationship between the duration of ADT and PSA response to CT.

There were a few limitations in our study. First, this is a retrospective study. Second, the most important parameter that defined the treatment outcome was the serum PSA level. Third, the sample size was not large enough.

According to our study, the response to secondary hormonal treatment in patients with lower PSA level and Gleason score is more significant than the others. First-line ADT duration can be a simple indicator for predicting the PFS and the outcome of secondary therapy. It can be proposed that shortterm response to ADT may predict shorter PFS and lower efficacy in patients treated with a new generation of AR-axis targeted drugs. However, further studies including large patient series are required to confirm these findings.

\section{REFERENCES}

1. Ferlay J, Soerjomataram I, Dikshit R, et al. Cancer incidence and mortality worldwide: sources, methods and major patterns in GLOBOCAN 2012. Int J Cancer 136: E359-86, 2015.

2. Haas GP, Delongchamps N, Brawley OW, et al. The worldwide epidemiology of prostate cancer: perspectives from autopsy studies. Can J Urol 15: 3866-3871, 2008.

3. Huggins C, Hodges CV. Studies on prostatic cancer: I. The effect of castration, of estrogen and of androgen injection on serum phosphatases in metastatic carcinoma of the prostate. Ca Cancer J Clin 22: 9-12, 1972.

4. Fizazi K, Scher HI, Molina A, et al. Abiraterone acetate for treatment of metastatic castration-resistant prostate cancer: final overall survival analysis of the COU-AA-301 randomised, double-blind, placebo-controlled phase 3 study. Lancet Oncol 13: 983-992, 2012.
5. Ryan CJ, Smith MR, Fizazi K, et al. Abiraterone acetate plus prednisone versus placebo plus prednisone in chemotherapy-naive men with metastatic castration-resistant prostate cancer (COU-AA-302): final overall survival analysis of a randomised, double-blind, placebo-controlled phase 3 study. Lancet Oncol 16: 152-160, 2015.

6. Scher HI, Fizazi K, Saad F, et al. Increased survival with enzalutamide in prostate cancer after chemotherapy. N Engl J Med 367: 1187-197, 2012.

7. Beer TM, Armstrong AJ, Rathkopf DE, et al. Enzalutamide in metastatic prostate cancer before chemotherapy. N Engl J Med 371: 424-433, 2014.

8. Scher HI, Halabi S, Tannock I, et al. Design and end points of clinical trials for patients with progressive prostate cancer and castrate levels of testosterone: recommendations of the Prostate Cancer Clinical Trials Working Group. J Clin Oncol 26: 1148-159, 2008.

9. Eisenhauer EA, Therasse P, Bogaerts J, et al. New response evaluation criteria in solid tumours: revised RECIST guidelines (version 1.1). Eur J Cancer 45: 228-247, 2009.

10. Antonarakis ES, Lu C, Wang $\mathrm{H}$, et al. AR-V7 and resistance to enzalutamide and abiraterone in prostate cancer. N Engl J Med 371: 1028-1038, 2014.

11. Chi KN, Kheoh T, Ryan CJ, et al. A prognostic index model for predicting overall survival in patients with metastatic castration-resistant prostate cancer treated with abirateroneacetate after docetaxel. Ann Oncol 27: 454-460, 2016.

12. Facchini $G$, Caffo $O$, Ortega $C$, et al. Very early PSA response to abiraterone in $\mathrm{mCRPC}$ patients: a novel prognostic factor predicting overall survival. Front Pharmacol 7: 123, 2016.

13. Ross RW, Xie W, Regan MM, et al. Efficacy of androgen deprivation therapy (ADT) in patients with advanced prostate cancer: association between Gleason score, prostate-specific antigen level, and prior ADT exposure with duration of ADT effect. Cancer 112: 1247-1253, 2008.

14. Pezaro C, Omlin A, Lorente D, et al. Visceral disease in castration-resistant prostate cancer. Eur Urol 65: 270-273, 2014.

15. Loriot $\mathrm{Y}$, Eymard JC, Patrikidou A, et all. Prior long response to androgen deprivation predicts response to next-generation androgen receptor axis targeted drugs in castration resistant prostate cancer. Eur J Cancer 51: 1946-1952, 2015.

16. Li JR, Wang SS, Yang CK, et all. First Line Androgen Deprivation Therapy Duration Is Associated with the Efficacy of Abiraterone Acetate Treated Metastatic Castration-Resistant Prostate Cancer after Docetaxel. Front Pharmacol 8: 55, 2017

17. Ross RW, Oh WK, Xie W, et al. Inherited variation in the androgen pathway is associated with the efficacy of androgendeprivation therapy in men with prostate cancer. J Clin Oncol 26: 842-847, 2008. 
International Journal of Hematology and Oncology

18. Angelergues A, Maillet D, Flechon A, et al. Duration of response to androgen-deprivation therapy (ADT) and efficacy of secondary hormone therapy, docetaxel (D), and cabazitaxel (C) in metastatic castration-resistant prostate cancer (mCRPC). J Clin Oncol 32 (Suppl 4): 282, 2014.

19. Bournakis E, Efstathiou E, Varkaris A, et al. Time to castration resistance is an independent predictor of castration-resistant prostate cancer survival. Anticancer Res 31: 1475-1482.

20. Giacinti S, Carlini P, Roberto M, et al. Duration of response to first androgen deprivation therapy, time to castration resistance prostate cancer, and outcome of metastatic castration resistance prostate cancer patients treated with abiraterone acetate. Anticancer Drugs 28: 110-115, 2017.

21. Hung J, Taylor AR, Divine GW, et al. The effect of time to castration resistance on outcomes with abiraterone and enzalutamide in metastatic prostate cancer. Clin Genitourin Cancer 14: 381-388, 2016.

\section{Correspondence:}

Dr. Goksen INANC IMAMOGLU

Saglik Bilimleri Universitesi

Diskapi Yildirim Beyazit Egitim ve Arastirma Hastanesi

Tibbi Onkoloji Bolumu

Diskapi, ANKARA / TURKEY

Tel: (+90-505) 2543846

e-mail: gokseninanc@hotmail.com 